curring over most of southeastern Canada and the eastern United States. Few are seen in the open, but individuals may often be collected under boards, stones and similar cover.

Logier and Toner (1961, p. 64) record the species from Crooked Lake, Grenfell, Hazelcliffe and Langenburg on the basis of specimens in the Saskatchewan Museum of Natural History and the University of Saskatchewan collection.

The Green Snake is bright green above and white or yellowish below. It is only slightly larger than the Red-bellied Snake, rarely reaching two feet in total length. Saskatchewan specimens vary from eleven to sixteen inches.

Two subspecies are recognized, an eastern form, Opheodrys vernalis vernalis, which has 130 or fewer ventral scales in males, 139 or fewer in females; and a western form, Opheodrys vernalis blanchardi which has a higher ventral scale count. Saskatchewan individuals examined had counts of 129 and 130 for males and 136, 138 and 142 for females. Manitoba specimens having similar intermediate counts were considered intergrades between the two subspecies by Grobman (1941). At least until more specimens are available, Saskatchewan individuals are best placed in the same category. Logier and Toner (1961, p. 76) regarded the Saskatchewan form as $O$. v. blanchardi on the basis of geographic range, but had not examined the existing specimens.

The Green Snake is a snake of moist grasslands and is absent in arid regions. Owing to its protective coloration it is rarely seen in the open, but may be found under various suitable cover as in the preceding species.

The known western limit of the Green Snake in Canada was established by a specimen collected by $\mathrm{Mr}$. Glenford Bellrose of Coronach. It was taken on July 12,1960 , on the SE $1 / 4-13-2-27 \mathrm{~W} 2$, near the doorstep of a farmhouse. The area surrounding the farmyard is cultivated farmland and one-half mile east of the farm is pasture land with a creek flowing through it. Another specimen was reported by $\mathrm{Mr}$. Bellrose on the $\mathrm{NE} 1 / 4-30-2-25$ W2 in the same type of area, beside a spring where water is available at all times.

Locality records cited by Logier and Toner (1961, p. 76) are Ceylon, Crooked Lake, Katepwa Beach, North Portal, and Roche Percee and are based on specimens in the Saskatchewan Museum of Natural History and National Museum of Canada. Additional specimens from Indian Head, Round Lake, and Whitewood are recorded by the Saskatchewan Museum of Natural History.

\section{REFERENCES}

CONANT, ROGER, 1958. A Field Guide to Reptiles and Amphibians of the United States and Canada east of the 100th Meridian. Houghton, Mifflin Co., Boston.

GROBMAN, A. B., 1941. A contribution to the knowledge of the variation in Opheodrys vernalis (Horton) with the description of a new subspecies. Misc. Pub. Mus. of Zool. Univ. Mich. No. 50, pp. 1-38.

LOGIER, E. B. S., and G. C. TONER, 1955. Check-List of the Amphibians and Reptiles of Canada and Alaska. Roy. Ont. Mus. Zool. Contrib. No. 41.

LOGIER, E. B. S., and G. C. Toner, 1961. Cheok-List of the Amphibians and Reptiles of Canada and Alaska. 2nd Ed. Life Sciences Division, Royal Ontario Museum, Contribution No. 53.

\title{
Phyllopod Crustaceans
}

\author{
by Hugh McLaughlin, Lewvan
}

\begin{abstract}
"Phyllopod crustaceans are among the most graceful and attractive inhabitants of fresh water pools." So begins a chapter on this group of crustaceans in Fresh Water Biology by Ward and Whipple. I would suggest that introduction to this type of water life begin on hands and knees beside a roadside ditch in early spring. Fairy Shrimp will be there and can be depended on to fascinate any student of nature.

Crustaceans are essentially aquatic
\end{abstract}

arthropods. The name tells that they are chitinous-armoured creatures with jointed legs. The higher crustaceans, including the lobsters and crayfish, are grouped together as the Malacostraca. The smaller crustacea may be grouped together as the Entomostraca. Among the most primitive and most fascinating of the Entomostraca are the Phyllopoda or Branchiopoda, the gill-footed crustacea. The leaf-life appendages serve both for locomotion and for breathing 


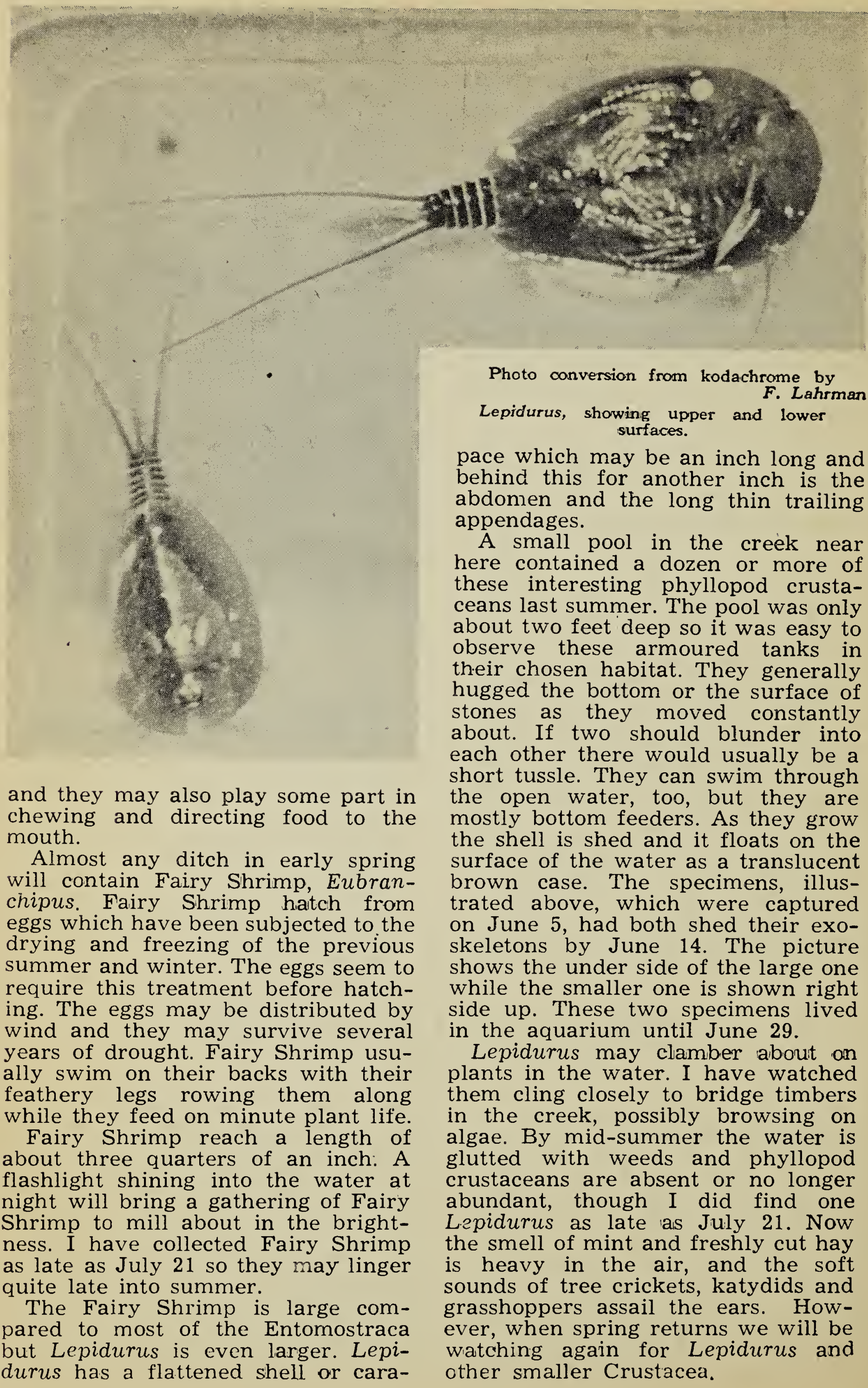

